Research Article

\title{
Maximization of Site-Specific Solar Photovoltaic Energy Generation through Tilt Angle and Sun-Hours Optimization
}

\author{
Macben Makenzi $\mathbb{D}^{1},{ }^{1}$ Joseph Muguthu $\mathbb{D}^{2},{ }^{2}$ and Evan Murimi $\mathbb{D}^{1}$ \\ ${ }^{1}$ Department of Mechatronic Engineering, Jomo Kenyatta University of Agriculture and Technology, Juja, Kenya \\ ${ }^{2}$ Department of Energy Technology, Kenyatta University, Nairobi, Kenya \\ Correspondence should be addressed to Macben Makenzi; mmackenzi@jkuat.ac.ke
}

Received 21 May 2020; Revised 20 October 2020; Accepted 29 October 2020; Published 11 November 2020

Academic Editor: Jing Shi

Copyright (c) 2020 Macben Makenzi et al. This is an open access article distributed under the Creative Commons Attribution License, which permits unrestricted use, distribution, and reproduction in any medium, provided the original work is properly cited.

\begin{abstract}
Many photovoltaic solar projects do not achieve optimum energy and power outputs due to poor technical sizing and system design approaches. Concerns on low-conversion rates, high intermittencies, and high-capital costs still haunt PV projects. The establishment of design methodologies that would result in increased outputs from solar arrays is crucial in addressing the aforementioned issues. The tilt angles of installed PV modules are critical factors that influence the power output of solar modules. Several resources are available that provide generic linear fits and estimation of tilt angles for various global regions. However, very few are capable of determining precise, location-specific tilt angles that would allow for optimal power output and energy generation. This paper presents a methodology developed to establish the optimum tilt angles for solar panels installed at specific locations, thus ensuring maximum energy generation. The modeling is based on the maximization of the solar irradiation incident on the surface of a PV panel by considering multiple site-specific variables. Different sets of transcendent equations have been derived which were used to calculate optimum tilt angles and the subsequent energy generation from specific configurations of photovoltaic arrays. The resulting algorithms were used to determine optimum tilt angles and energy generation for solar PV installations in Athi River, Kenya. Dynamic and static optimal tilt angles were compared with the region's baseline industry practice of using a fixed tilt angle of $15^{\circ}$. It was observed that the dynamic tilt angles improved the daily solar energy output by up to $6.15 \%$, while the computed optimal static tilt angle provided a $2.87 \%$ output increment. This improvement presents a significant impact on the technical specification of the PV system with a consequent reduction in the investment and operational cost of such installations. It further demonstrated that the use of the optimum static tilt angle results in cost and space savings of up to $2.8 \%$ as compared to the standard industry practice. Additionally, $5.8 \%$ cost and space savings were attained by the utilization of dynamic tilt angles.
\end{abstract}

\section{Introduction}

Clean energy is already being utilized in numerous sectors in many developed countries, either directly providing power on-site or indirectly via the existing energy generation and supply systems [1]. Unfortunately, for most developing countries, the electricity supply is either unreliable, insufficient, or totally absent. This has led to the sustained use of fossil fuels resulting in a host of environmental issues at local, regional, and global scales, reduced quality of life, and endangering the human health as well as the well-being of present and future generations of humankind [2]. In China, for example, greenhouse gas emissions from energy use in irrigation are equivalent to $50-70 \%$ of total emissions from agriculture. $61 \%$ of irrigation greenhouse gas emissions in China emanates from groundwater pumping [3]. In India, groundwater pumping for irrigation accounts for up to $12 \%$ of all GHG emissions. Agriculture in this country is responsible for up to $58 \%$ of GHG produced. Also, the continued reliance on fossil fuels in the water pumping sector creates a high risk of fluctuating prices, potentially making food unaffordable for the economically weak. With the finite availability of fertile arable land and an increase in food demand, irrigation which can be done all year round is 
increasingly being adopted in many areas. As compared to rain-fed systems, irrigated land produces up to three times more than the latter. Solar PV energy is a viable solution to the above concerns [4]. If designed well and maintained properly, these systems can provide the required energy sufficiently. Photovoltaic modules convert solar radiation directly into electricity. This conversion is influenced by various factors including scattering and absorption of direct solar radiation (DSR) by the atmosphere, tilt angle of the PV solar panels, and declination and efficiency of the PV solar panels [5].

Kenya receives a considerable amount of solar radiation. This is because of its location, lying on the equator and extending four degrees on either side. Insolation levels ranging from 4 to $7 \mathrm{kWh} / \mathrm{m}^{2} /$ day are experienced in Kenya. Kenya's solar insolation is estimated at more than 23,000 TWh/year [6]. Therefore, a high potential for solar power generation does exist in the country. Apart from the environmental, technoeconomic, and social benefits, largescale adoption of solar energy is also incentivised by several other factors which include low-electrification rates, ongoing technological progress, and related substantial fall in cost for PV systems. In this regard, the adoption of solar energy has been identified as an important platform necessary for sustainable development. Global warming and climate change mitigation require a transition from fossil fuels to cleaner energy sources $[7,8]$.

Many solar PV projects fail to achieve high success rates for various reasons. One of the major reasons is that if not well planned, these projects end up not being competitive in the energy market which is dominated by fossil sources. The systems suffer from low-conversion rates and high intermittencies, and ultimately high-capital costs [9]. Therefore, a key requirement to ensure the successful deployment of solar PV is the development of high conversion-efficiency technologies. PV conversion efficiencies depend on the magnitude of the direct solar radiation (DSR) incident on the module surface. This is affected by the tilt angle, the location's latitude, and the day of the year under consideration. As the day of the year and the latitude are factors that cannot be changed, the tilt angle remains a critical factor influencing the efficiency of conversion of the solar panel $[10,11]$.

Although there exist theoretical recommended tilt angles for solar panels for general locations, the information is usually quite generic and not available for specific sites. Sometimes, adjustments of PV module tilt angles for specific locations are necessary to ensure optimum generation. In Kenya, for example, such location-specific data on tilt angles are not available as such, and all installed solar panels are set up using a fixed theoretical tilt angle. Therefore, there is a need to determine the optimum tilt angles for specific sites under consideration. In this study, a methodology for the determination of optimum tilt angles based on site-specific data is presented. Using this approach, the study determined the seasonal adjustments in tilt angles for PV modules for maximum solar energy generation in Athi River town in Kenya. Additionally, the approach developed, herein, produced results close to those obtained by highly complex algorithms [12].

\section{Review of Industry Practice in Determination of Solar PV Energy Output}

A critical factor in the determination of the efficiency of solar collectors in the conversion of solar radiation to heat or electricity is the tilt or inclination angle of the collector $[10,13]$. The output from a PV module increases with increased exposure to direct sunlight. Solar tracking systems provide the best approach towards achieving optimum tilt angles. They collect solar energy for the longest period of the day with precise alignment to the shifting of the sun's positions. Daily solar energy generated from a single axis system was seen to be $19 \%-24 \%$ higher than by a fixed system [14]. However, they are very expensive; they require energy for their operation and require additional retrofitting to make them applicable for PV setups [15]. Consequently, fixed PV systems are more popular.

Different resources exist that provide estimates of optimal tilt angles for certain locations. Some literature provides the values of $\lambda=\phi \pm 20^{\circ}, \lambda=\phi \pm 8^{\circ}, \lambda=\phi \pm 5^{\circ}$, and $\lambda=\phi \pm 15^{\circ}$ [16-18], where $\lambda$ represents the tilt angle and $\phi$ is the geographical latitude. In Kenya, for example, all major solar installation companies use a static tilt angle of $15^{\circ}$ for all installations regardless of the specific location in the country. The logic behind this is to provide a trade-off between the self-cleaning capability of such angles and the maximization of outputs [19]. The difference in the values is possibly a result of the different approaches in calculations for determination of the solar panel slope or the difference in empirical data and models utilized in the determination of diffuse solar radiance and its association to global radiation.

This study aimed to develop a novel and easily adaptable technique that would enable the attainment of the maximum possible energy generation from PV setups installed at specific geographical locations through the determination of optimum solar PV tilt angles. This would enable avoidance of the generalities in establishing regional PV module installation tilt angles. In this study, a methodology for the determination of site-specific optimum PV tilt angles is presented that will allow for a system design approach that ensures specific load demands are met without the common challenges of oversizing and undersizing PV systems and the subsequent high capital and space requirements.

\section{Photovoltaic Energy Generation: Overview}

3.1. Modeling of PV Cells. A PV module is made up of several PV cells connected in series and parallel. The cell constitutes a p-n junction that converts light energy into electricity. Its equivalent circuit is shown in Figure 1.

The current source $I_{p h}$ is the cell photocurrent, $R_{j}$ represents the nonlinear impedance of the p-n junction, and $R_{s h}$ and $R_{s}$ represent the intrinsic series and shunt resistance of the cell, respectively. PV cells are grouped into larger units called PV modules which are further interconnected in series-parallel configuration to form $\mathrm{PV}$ arrays or $\mathrm{PV}$ generators. The PV mathematical model used in this paper is presented in the following equation: 


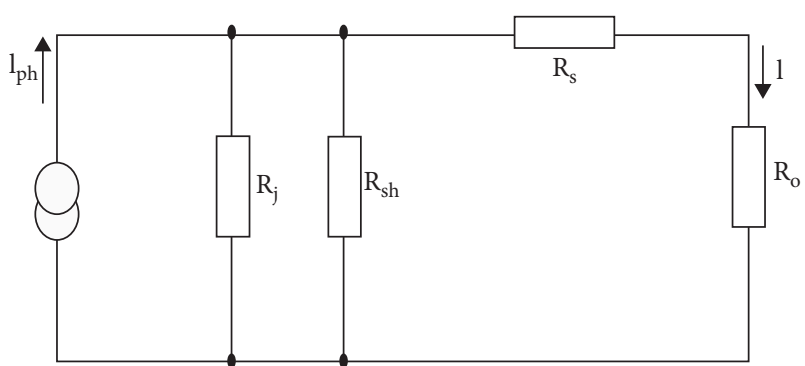

Figure 1: Equivalent circuit of a PV cell.

$$
I=\eta_{p} I_{p h}-\eta_{p} I_{r s}\left[\exp \left(\frac{q V}{k T A \eta_{s}}\right)-1\right],
$$

where $I$ is the PV array output current, $V$ is the PV array output voltage, $n_{s}$ is the number of cells in series, $n_{p}$ is the number of cells in parallel, $q$ is the charge of an electron, $k$ is Boltzmann's constant, $A$ is the p-n junction ideality factor, $T$ is the cell temperature, and $I_{r s}$ is the cell reverse saturation current. The cell deviation from the ideal $\mathrm{p}-\mathrm{n}$ junction characteristics is determined by the factor $A$ in equation (1). The cell reverse saturation current $\mathrm{I}_{r s}$ varies with temperature according to the following equation:

$$
I_{r s}=I_{r r}\left[\frac{T}{T_{r}}\right]^{3} \exp \left(\frac{q E_{G}}{k A}\left[\frac{1}{T_{r}}-\frac{1}{T}\right]\right),
$$

where $T_{r}$ is the cell reference temperature, $I_{r r}$ is the cell reverse saturation temperature at $T_{r}$, and $E_{G}$ is the bandgap of the semiconductor used in the cell. The temperature dependence of the energy gap of the semiconductor is given in the following equation:

$$
E_{G}=E_{G}(0)-\frac{\alpha T^{2}}{T+\beta} .
$$

The photocurrent $I_{p h}$ depends on the solar radiation and cell temperature, and the relationship is indicated in the following equation:

$$
I_{p h}=\left[I_{s c r}+K_{i}\left(T-T_{r}\right)\right] \frac{S}{100},
$$

where $I_{s c r}$ is the cell short-circuit current at the reference temperature and radiation, $K_{i}$ is the short-circuit current temperature coefficient, and $S$ is the solar radiation in $\mathrm{mW} /$ $\mathrm{cm}^{2}$. The PV power can be calculated using the following equation :

$$
P=\eta_{p} I_{p h} V\left[\left(\frac{q v}{k T A \eta_{s}}\right)-1\right] .
$$

3.2. Solar Radiation and Energy. Radiation from the sun as it reaches the Earth varies due to diffusion and absorption of that energy in the atmosphere. Maximum solar radiation falls on the Earth's surface when the sun is directly overhead. Sunlight has to travel the shortest path when the sun is overhead and has to travel the longest path when it is along the horizon [20]. The path defined as air mass (AM) can be approximated by the following equation:

$$
\mathrm{AM}=\frac{1}{\cos (Z)},
$$

where $Z$ is the zenith angle, i.e., the angle between the sun and the vertical. Once per day, the Earth rotates around its polar axis. The Earth is slightly tilted at an angle of $23.45^{\circ}$. Declination angle $(\delta)$ is defined as the angle between a ray of the sun when extended to the center of the Earth and the equatorial plane [21]. It depends on the day of the year. If " $d$ " is considered any given day of the year and angles of the north are taken as positive and the angles of the south are taken as negative, then the declination angle is calculated using the following equation [22]:

$$
\delta=23.45^{\circ} \sin \left(\frac{360(d-81)}{365}\right) \text {. }
$$

Declination is important because it enables the location of the position of the sun in the sky at any time of the year. Any location on the Earth can be determined accurately with the help of its respective latitude and longitude. The latitude $\varphi$ is normally written in this format: degrees, minutes, and seconds. The sunrise and sunset angle of a location on a particular day of the year is determined using the following equation [23]:

$$
\omega_{s}=\cos ^{-1}(-\tan \varphi \tan \delta) .
$$

The sunrise angle can be considered as $-\omega_{s}$ and the sunset angle as $+\omega_{s}$. The difference between the sunrise and the sunset angle is calculated using the following equation:

$$
\Delta \omega=\left(2 \times \omega_{s}\right) .
$$

From the sunrise and sunset time $T_{S R}$ and $T_{S S}$, respectively, of the particular day in consideration, the difference between them is defined as $\Delta T$ and is calculated as shown in the following equation:

$$
\Delta T=T_{S S}-T_{S R} .
$$

Hour angle, $\omega(t)$, is the difference between noon and a particular time of the day with $t$ in terms of $360^{\circ}$ rotation in 24 hours:

$$
\omega(t)=-\omega_{S} \frac{2 \omega_{S}}{\Delta T} X\left(t-T_{S R}\right) .
$$

Now, using the hour angle, it is possible to calculate the solar altitude, $\alpha$. This is the angle between the horizon and the incident solar ray that is falling on that particular latitude. The solar altitude is found using the following equation:

$$
\sin \alpha=\sin \delta \sin \varphi+\cos \delta \cos \varphi \cos \omega(t) .
$$

Scattered or absorbed, the amount of sunlight depends upon the extent to which it has to travel through to the Earth's surface. A direct perpendicular path to the sea level designated as AM1 (air mass =1) can be compared to the aforementioned length of the path to the Earth's surface. The 
total extraterrestrial energy density that reaches the top of the Earth's atmosphere (AM0) from the sun is $1367 \mathrm{~W} / \mathrm{m}^{2}$. After taking into account absorption, at AM1, the global radiation intensity of $1367 \mathrm{~W} / \mathrm{m}^{2}$ decreases to $1000 \mathrm{~W} / \mathrm{m}^{2}$ at the sea level. Compared to the original AM0 value, the intensity of sunlight has decreased to $70 \%$ at AM1. This intensity $\mathrm{I}_{D}$ can be expressed by the following equation:

$$
I_{D}=1367(0.7)^{\mathrm{AM}} \text {. }
$$

In order to find the optimum angle for installing the solar panels, different tilt angles $(\lambda)$ are used. The tilt angle is the angle between the solar panel and the horizontal plane. In this research, the tilt angles taken were optimized for each of the months in a year. This angle is south oriented in the northern hemisphere and north oriented in the southern hemisphere, and it is calculated using the following equation [24]:

$$
\lambda=\left|\varphi-\delta_{\text {ave }}\right|
$$

where $\delta_{\text {ave }}$ is the average declination and it is calculated using the following equation. The total deflection and number of days in the equation refer to the sum of the individual deflections and count of days, respectively, as applied when using equation (7):

$$
\delta_{\text {ave }}=\frac{\text { total declination }}{\text { number of days }} \text {. }
$$

The angle between the incident sunlight and the panel normal is $\theta$ and is calculated using the following equation:

$$
\cos \theta=\sin (\varphi-\lambda) \sin \delta+\cos (\varphi-\lambda) \cos \delta \cos \omega(t) .
$$

Finally, to calculate the solar intensity that will fall on the solar panel surface, $I_{P}$ is used in the following equation:

$$
I_{P}=I_{D} \cos \theta .
$$

With the help of MATLAB, the energy received by the solar panels was calculated for the $15^{\text {th }}$ day of each of the months of the year, this being the average middle day of the month. For the particular day, the panel intensity is integrated by its corresponding sunrise to sunset time to give us the total energy of the day $\left(\mathrm{kWh} / \mathrm{m}^{2} /\right.$ day $)$. Different tilt angles of the panels are then used to calculate different sets of energy calculations for the mentioned months.

\section{Results and Discussion}

Athi River, Kenya, lying at a latitude of $1.4753^{\circ} \mathrm{S}$ and $36.95777^{\circ} \mathrm{E}$ was identified for validation of the models developed. The respective sunrise and sunset times for this location are presented in Table 1. The solar PV energy demand required for this location was analysed monthly for a period of one year. Using the models developed in this research work, the optimized tilt angles, individual intensities, and the respective energy generation were calculated for the respective months. Using MATLAB, the energy received by the solar panels was calculated for the $15^{\text {th }}$ day of each month of the year. For each of these days, the panel
TABLE 1: Sunrise and sunset times.

\begin{tabular}{lcc}
\hline & Sunrise time & Sunset time \\
\hline January & $06: 35$ & $18: 47$ \\
February & $06: 41$ & $18: 51$ \\
March & $06: 38$ & $18: 45$ \\
April & 6.3 & $18: 34$ \\
May & $06: 27$ & $18: 30$ \\
June & $06: 31$ & $18: 33$ \\
July & $06: 37$ & $18: 39$ \\
August & $06: 35$ & 18.39 \\
September & $06: 25$ & $18: 30$ \\
October & $06: 14$ & $18: 22$ \\
November & $06: 11$ & $18: 22$ \\
December & $06: 21$ & $18: 33$ \\
\hline
\end{tabular}

It outlines the sunrise and sunset times for the 15th day of each month of the year for Athi River site.

intensity was then integrated by its corresponding sunrise to sunset time to give the total energy achievable for the day (kWh/m²/day).

4.1. Calculation of Optimized Tilt Angle. Using MATLAB and equations described previously, the optimum monthly declination angles were modeled. Figure 2 shows the relationship between the respective days of the year and their equivalent declination angles. During the equinoxes, i.e., the $22^{\text {nd }}$ of March and the $22^{\text {nd }}$ of September, the declination is zero. The declination is positive during the northern hemisphere summer and negative during the northern hemisphere winter. It reaches a maximum of $23.45^{\circ}$ during the summer solstice in the northern hemisphere, i.e., on the $22^{\text {nd }}$ of June. The declination is recorded as minimum at $-23.45^{\circ}$ during the winter solstice in the northern hemisphere on December 21-22. Average monthly tilt angles $(\lambda)$ were calculated using equation (14). Table 2 gives a summary of the tilt angles obtained for the site.

The tilt angles were seen to vary from a minimum of $3.02^{\circ}$ to a maximum of $24.57^{\circ}$. The values were noted to correspond with those found in some literature for regions proximal to the site used in this study [12].

4.2. Solar PV Energy Generation at Optimized Tilt Angles. To study the effect of the tilt angles, each monthly tilt angle was used to compute the average daily solar energy for each month of the year. Using the equations presented previously and the respective sunrise and sunset times for the location, the modeled panel intensity is integrated by its corresponding sunrise to sunset time to give us the total energy output per day. The results are illustrated in Figures 3 and 4.

It is observed that there are variations in the average daily solar energy outputs for each month of the year at the different tilt angles. A general profile is, however, observed whereby, regardless of the specific tilt angle in consideration, the months of May, June, and July exhibit the lower daily averages of energy outputs annually. Combining all the total solar energy bar graphs into a single one from January to December gives us a bar graph consisting of 12 bars in a group for each month illustrated in Figure 5. 


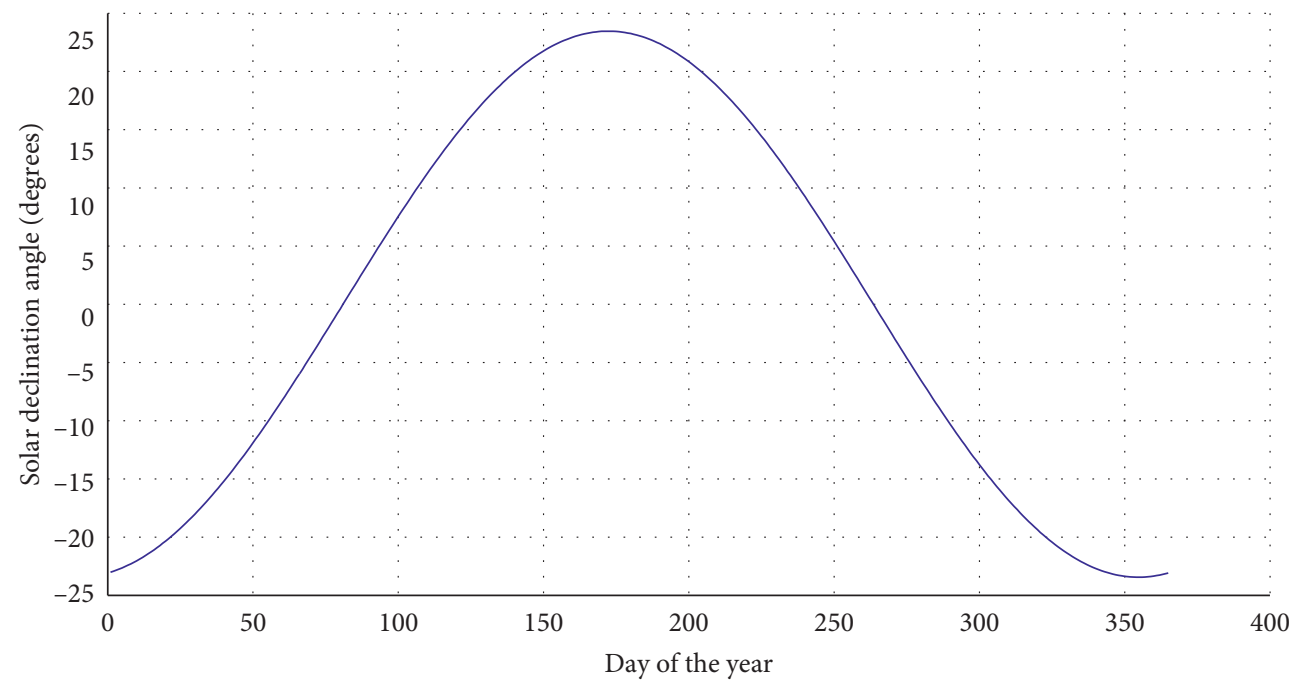

Figure 2: Yearly variance of declination angle.

TABle 2: Computed monthly PV module tilt angles.

\begin{tabular}{lccccccccccc}
\hline$\lambda_{\text {Jan }}$ & $\lambda_{\text {Feb }}$ & $\lambda_{\text {Mar }}$ & $\lambda_{\text {Apr }}$ & $\lambda_{\text {May }}$ & $\lambda_{\text {Jun }}$ & $\lambda_{\text {Jul }}$ & $\lambda_{\text {Aug }}$ & $\lambda_{\text {Sep }}$ & $\lambda_{\text {Oct }}$ & $\lambda_{\text {Nov }}$ & $\lambda_{\text {Dec }}$ \\
\hline $22.32^{\circ}$ & $14.62^{\circ}$ & $4.31^{\circ}$ & $8.02^{\circ}$ & $17.33^{\circ}$ & 21.60 & $19.63^{\circ}$ & $11.82^{\circ}$ & $3.02^{\circ}$ & $11.32^{\circ}$ & $20.53^{\circ}$ & $24.57^{\circ}$ \\
\hline
\end{tabular}

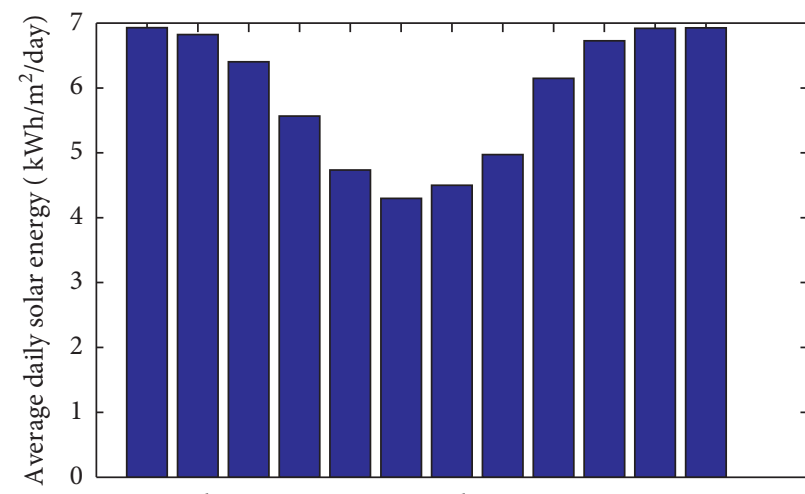

Jan Feb Mar Apr May Jun Jul Aug Sep Oct Nov Dec Months

(a)

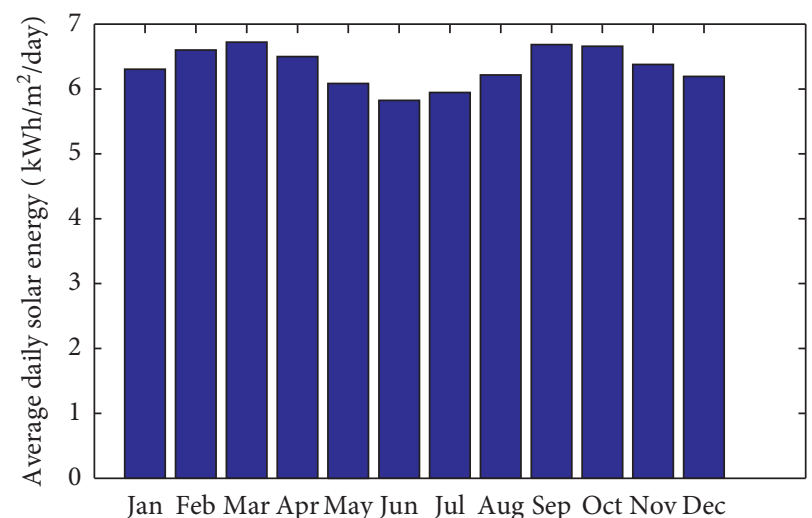
Months

(c)

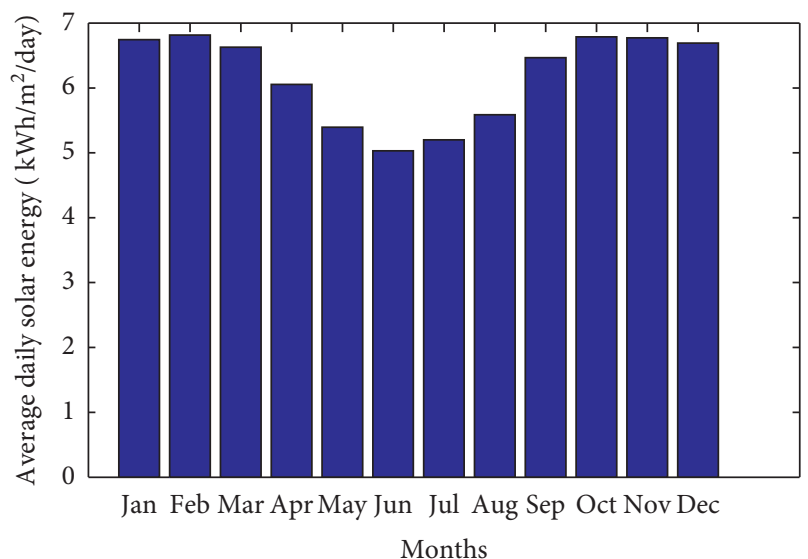

(b)

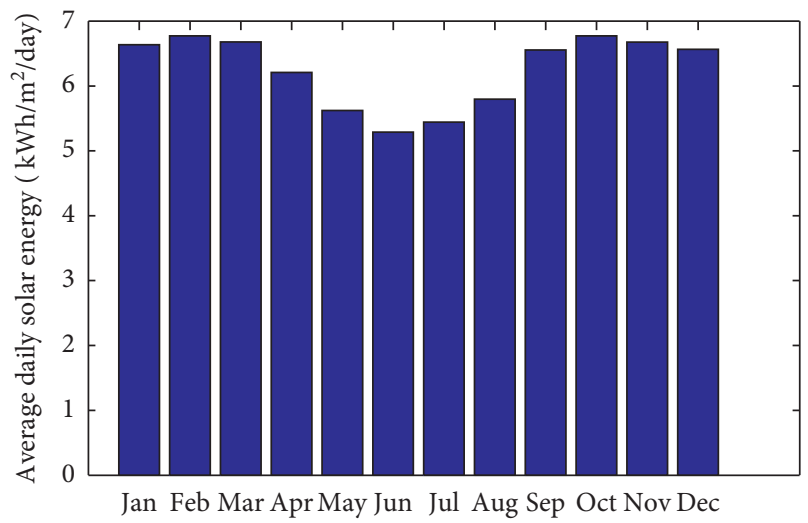

Months

(d)

Figure 3: Continued. 




Jan Feb Mar Apr May Jun Jul Aug Sep Oct Nov Dec Months

(e)

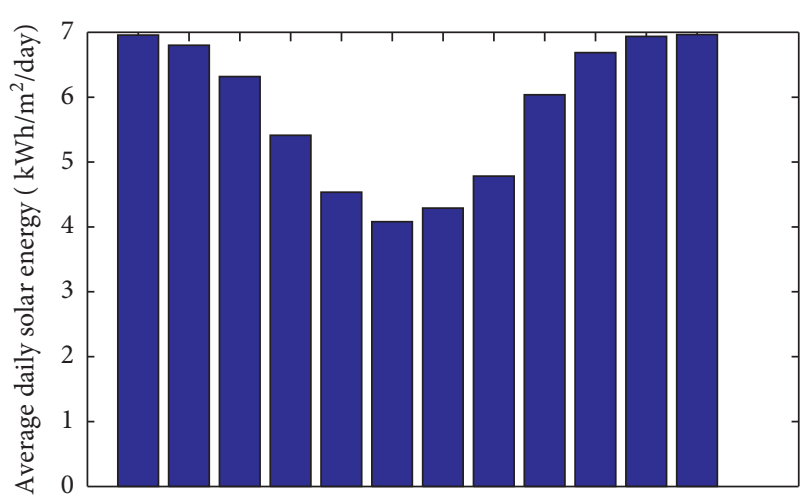

Jan Feb Mar Apr May Jun Jul Aug Sep Oct Nov Dec Months

(f)

FIGURE 3: PV energy outputs at monthly optimized angles: January to June: (a) PV energy output at $\lambda_{\text {Jan; }}$; (b) PV energy output at $\lambda_{\text {Feb }}$; (c) PV energy output at $\lambda_{\text {Mar }}$; (d) PV energy output at $\lambda_{\text {Apr }}$; (e) PV energy output at $\lambda_{\text {May }}$; (f) PV energy output at $\lambda_{\text {Jun }}$.

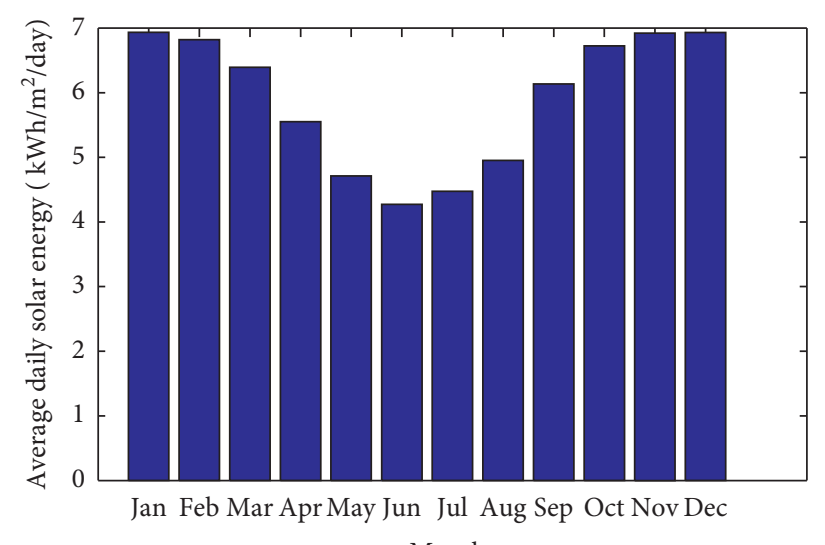

Months

(a)

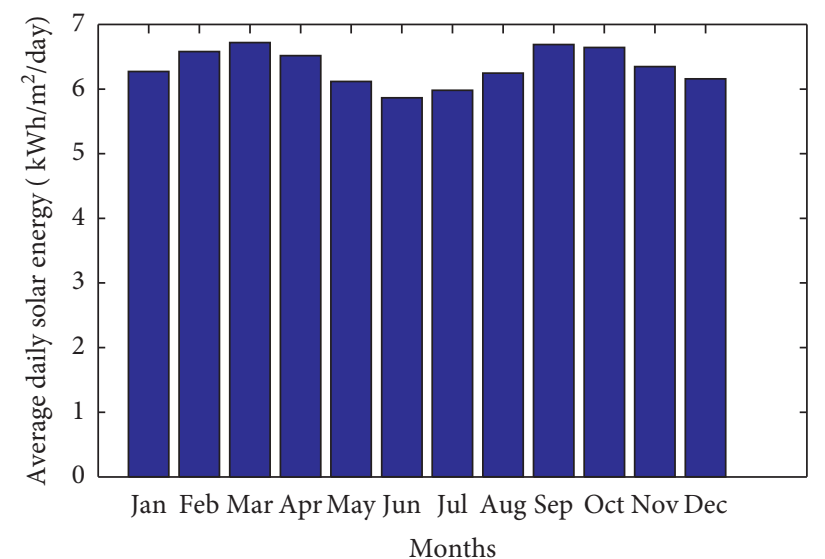

(c)

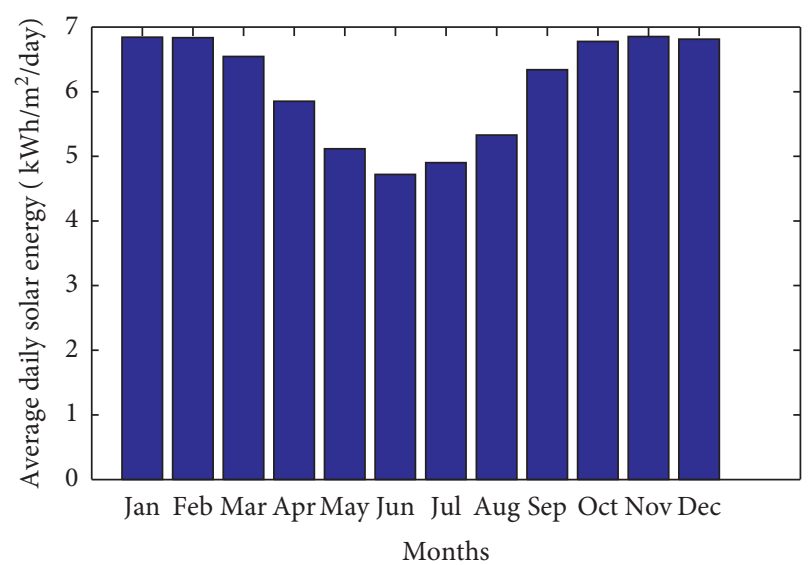

(b)

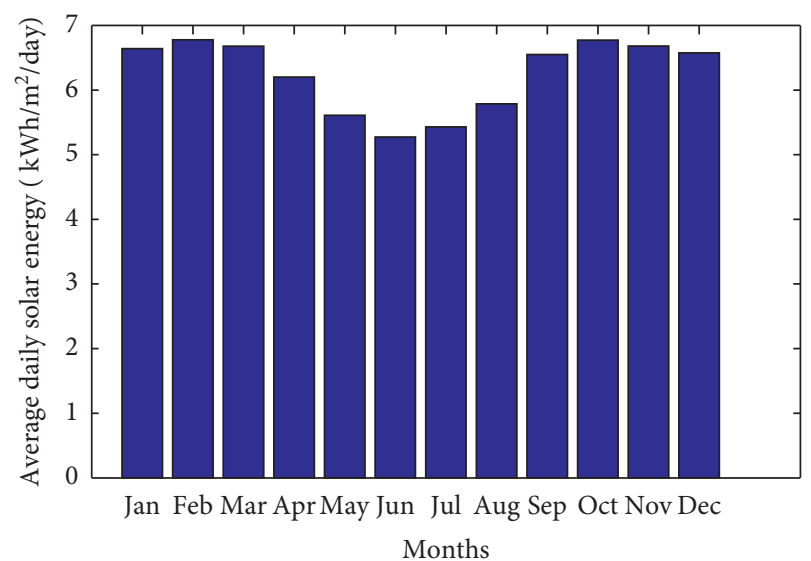

(d)

Figure 4: Continued. 




Jan Feb Mar Apr May Jun Jul Aug Sep Oct Nov Dec Months

(e)

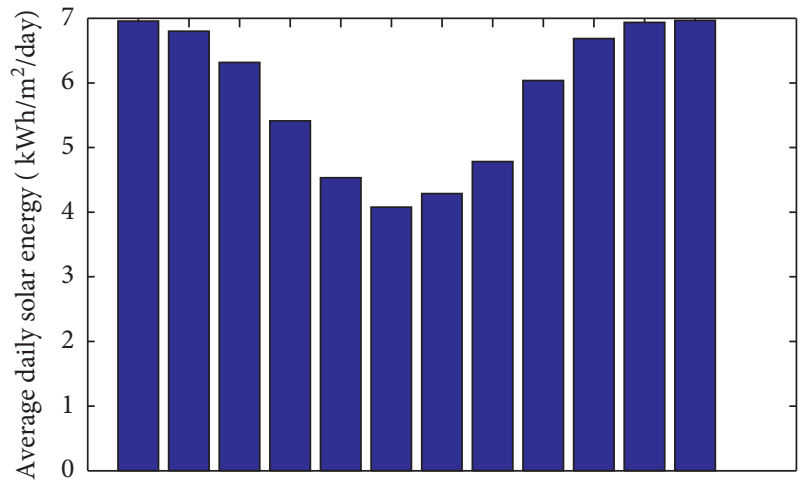

Jan Feb Mar Apr May Jun Jul Aug Sep Oct Nov Dec Months

(f)

FIgURe 4: PV energy outputs at monthly optimized angles: July to December: (a) PV energy output at $\lambda_{\text {Jul }}$; (b) PV energy output at $\lambda_{\text {Aug; }}$; (c) PV energy output at $\lambda_{\text {Sep }}$; (d) PV energy output at $\lambda_{\text {Oct }}$; (e) PV energy output at $\lambda_{\text {Nov }}$; (f) PV energy output at $\lambda_{\text {Dec }}$.

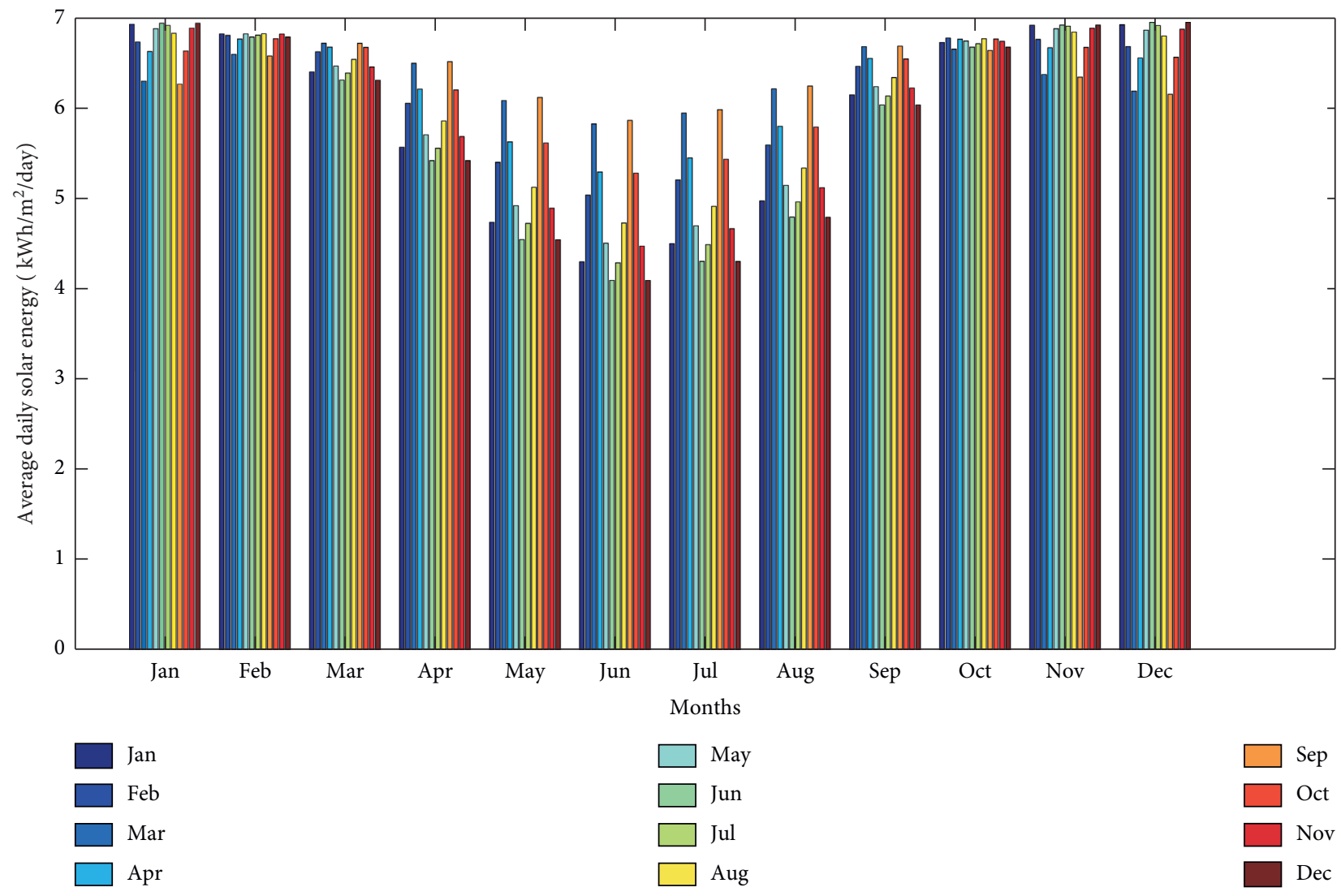

FIGURE 5: Monthly average daily solar energy bar graph for different optimized tilt angles.

The exact values from MATLAB are presented in Tables 3 and 4 overleaf. An analysis of the data indicates that throughout all the monthly tilt angles, the month of June experiences the energy outputs with the lowest $(4.0916 \mathrm{kWh} /$ day) being experienced at a tilt angle of $\lambda_{\text {Dec }}$. It was also observed that a tilt angle of $\lambda_{\text {Dec }}$ would give the highest energy per day in the yearly span in the month of December $(6.9497 \mathrm{kWh} /$ day $)$. This paper presents the research results of four configurations that were investigated in order to validate the models developed herein. The first configuration entailed the utilization of a fixed tilt angle of $15^{\circ}$. This setup was considered as the baseline as this installation tilt angle is accepted as the standard industry practice in Kenya. The second configuration entailed the use of the specific monthly tilt angles for the respective month, as obtained in the previous section. This required the changing of the module 
tilt orientations every month to the specified angles in $\mathrm{Ta}$ ble 2 . The third configuration entailed utilization of a static optimized tilt angle that would provide the largest energy output throughout the year. This was established to be the tilt angle $\lambda_{\text {Sep }}$, as illustrated in Table 4 .

The fourth configuration involved the use of a dynamic setup requiring the variation in the panel orientation every month. In this setup, the PV modules were oriented to the specific tilt angle established to generate the highest energy output for that particular month as per Tables 3 and 4 . The performance of the three scenarios is summarized in Table 5.

Several observations are made from Table 5 . In the baseline configuration, a fixed tilt angle of $15^{\circ}$ generated an annual average total of $73.9939 \mathrm{kWh} / \mathrm{m}^{2} /$ day with the monthly averages coming in at $6.1662 \mathrm{kWh} / \mathrm{m}^{2} /$ day. In the second configuration, which entailed the generation of $\mathrm{PV}$ output using the previously calculated static monthly tilt angles for the respective months of the year, an annual average total of $72.7946 \mathrm{kWh} / \mathrm{m}^{2} /$ day was obtained with the monthly average being recorded at $6.066217 \mathrm{kWh} / \mathrm{m}^{2} /$ day. From Tables 3 and 4, it is deduced that the highest energy output is obtained by setting the tilt angle to $\lambda_{\text {sep. }}$ A setup designed to use this tilt angle throughout the months of the year (configuration 3) will give an annual total average of $76.1147 \mathrm{kWh} / \mathrm{m}^{2} /$ day with a monthly average of $6.3429 \mathrm{kWh} / \mathrm{m}^{2} /$ day. In the fourth configuration, which investigated a setup implemented by using the respective optimum monthly tilt angles for each month, a monthly average of $6.55 \mathrm{kWh} / \mathrm{m}^{2} /$ day is achievable throughout the year using the tilt angles calculated from the developed algorithm presented in this work. The annual total from this setup is observed to achieve average energy outputs of up to $78.5471 \mathrm{kWh} / \mathrm{m}^{2} /$ day. Therefore, using the optimum static tilt angle $\left(\lambda_{\text {sep }}\right)$ would improve daily solar energy output by up to $2.87 \%$ as compared to the current industry practice. On the contrary, the dynamic tilt angle would improve the solar output by up to $6.15 \%$. The optimized solar energy output from the PV modules enables the reduction of the project-specific and overall array size, and this consequently leads to reduced capital costs of the solar plant. This was demonstrated through the system design of a solar PV generator for a commercial farm in the same location $\left(1.4753^{\circ} \mathrm{S}\right.$ and $\left.36.95777^{\circ} \mathrm{E}\right)$. An initial energy audit indicated that the farm has an energy requirement of 100,000 Wh/day. System sizing was then undertaken for four setups based on the four configurations outlined in Table 4. Using the respective computed solar PV energy outputs for each configuration and fixing a static derating factor for each of the configurations, the required wattage for the respective PV generators was calculated. A 375Wp JKM375M-66H PV module [25] was selected for use in all the configurations and using the surface area specifications of the PV modules as detailed in the data sheet, and the overall area requirements for each of the setups were computed. According to the Bloomberg NEF solar spot price index [26], the global PV module price averages in the first five months of 2020 stood at $\$ 0.21 / \mathrm{W}$ for mono-c-Si modules, $\$ 0.19 / \mathrm{W}$ for multi-c-Si, and $\$ 0.10 / \mathrm{W}$ for polysilicon. Using this information, the cost of the PV arrays for each configuration is also calculated. The computations are summarized in Table 6 . It was observed that the use of the optimum static tilt angle $\left(\lambda_{\text {sep }}\right)$ results in a cost and space saving of up to $2.8 \%$ as compared to the standard industry practice, in this particular case. On the contrary, a 5.8\% cost and space savings were attained by the utilization of the dynamic tilt angle.

\section{Conclusion}

In this paper, a novel and easily adaptable technique that would enable the attainment of the maximum possible energy generation from PV setups installed at specific geographical locations through the determination of optimum solar PV tilt angles is presented. The approach has proved critical when developing subsequent technical models that would ensure optimal planning of solar PV powered projects such as solar water pumping (SWP) setups for specific environments. Using MATLAB, mathematical models were developed to study the operational parameters of solar cells. It was established that irradiance was the most influential parameter with regards to solar power output. Therefore, the work delved deeper into developing models that would ensure optimal utilization of available irradiance. Innovative, thorough, and intrinsic models were developed to determine optimal tilt angles while considering critical elements that are not usually included in generic sizing approaches. These parameters include the precise location of the site under consideration using global coordinate systems, exact daily sunrise and sunset times, specific period of the year, solar altitudes, and hour angles. Additionally, models for determining specific solar intensity profiles were developed. Optimal tilt angles were generated for various scenarios and cross comparisons were done to study their effects.

A site in Athi River, Kenya, was identified as a case study, and using the models developed, the optimum tilt angles were determined. The energy outputs from these angles were then simulated and analysed. Depending on the time of year, the monthly optimum tilt angles were determined to lie between $3.02^{\circ}$ and $24.57^{\circ}$. Four different configurations were investigated to validate the developed algorithm presented in this paper. In the baseline configuration, a fixed tilt angle of $15^{\circ}$ which is the industry standard in Kenya was observed to generate an annual average total of $73.9939 \mathrm{kWh} / \mathrm{m}^{2} /$ day with the monthly averages coming in at $6.1662 \mathrm{kWh} / \mathrm{m}^{2} /$ day. The second configuration analysed the generation of $\mathrm{PV}$ output using the previously calculated static monthly tilt angles for the respective months of the year. This setup provided an annual average total of $72.7946 \mathrm{kWh} / \mathrm{m}^{2} /$ day and a monthly average of $6.066217 \mathrm{kWh} / \mathrm{m}^{2} /$ day. The third configuration looked at a setup designed to use $\lambda_{\text {sep }}$ tilt angle throughout the months of the year. This produced an annual total average of $76.1147 \mathrm{kWh} / \mathrm{m}^{2} /$ day with a monthly average of $6.3429 \mathrm{kWh} / \mathrm{m}^{2} /$ day. The last configuration investigated a setup implemented by using the respective optimum monthly tilt angles for each month, and a monthly average of $6.55 \mathrm{kWh} / \mathrm{m}^{2} /$ day was seen to be achievable throughout the year. The annual total from this setup was obtained as $78.5471 \mathrm{kWh} / \mathrm{m}^{2} /$ day. Analysis of these results indicated that using the optimum static tilt angle $\left(\lambda_{\text {sep }}\right)$ 
TABLE 3: Average daily solar energy outputs for January to June tilt angles.

\begin{tabular}{|c|c|c|c|c|c|c|}
\hline \multicolumn{7}{|c|}{ Energy $\left(\mathrm{kWh} / \mathrm{m}^{2} /\right.$ day $)$} \\
\hline & $\lambda_{\text {Jan }}$ & $\lambda_{\mathrm{Feb}}$ & $\lambda_{\mathrm{Mar}}$ & $\lambda_{\mathrm{Apr}}$ & $\lambda_{\text {May }}$ & $\lambda_{\text {Jun }}$ \\
\hline January & 6.9295 & 6.7339 & 6.2994 & 6.6265 & 6.8818 & 6.9401 \\
\hline February & 6.8230 & 6.8061 & 6.5961 & 6.7669 & 6.8230 & 6.7883 \\
\hline March & 6.4023 & 6.6242 & 6.7189 & 6.6765 & 6.4675 & 6.3116 \\
\hline April & 5.5683 & 6.0555 & 6.4977 & 6.2109 & 5.7065 & 5.4187 \\
\hline May & 4.7352 & 5.4008 & 6.0854 & 5.6272 & 4.9215 & 4.5463 \\
\hline June & 4.2988 & 5.0376 & 5.8255 & 5.2940 & 4.5042 & 4.0933 \\
\hline July & 4.5003 & 5.2056 & 5.9461 & 5.4483 & 4.6970 & 4.3025 \\
\hline August & 4.9729 & 5.5931 & 6.2152 & 5.8013 & 5.1471 & 4.7941 \\
\hline September & 6.1476 & 6.4638 & 6.6809 & 6.5526 & 6.2388 & 6.0357 \\
\hline October & 6.7279 & 6.7786 & 6.6544 & 6.7652 & 6.7462 & 6.6770 \\
\hline November & 6.9203 & 6.7615 & 6.3732 & 6.6682 & 6.8823 & 6.9211 \\
\hline December & 6.9261 & 6.6827 & 6.1885 & 6.5570 & 6.8659 & 6.9494 \\
\hline Monthly average & 5.9127 & 6.1786 & 6.3401 & 6.2496 & 5.9902 & 5.8148 \\
\hline Annual totals & 70.952 & 74.143 & 76.081 & 74.994 & 71.881 & 69.778 \\
\hline
\end{tabular}

TABle 4: Average daily solar energy outputs for July to December tilt angles.

\begin{tabular}{lccccc}
\hline & & \multicolumn{2}{c}{ Energy $\left(\mathrm{kWh} / \mathrm{m}^{2} /\right.$ day $)$} & & \\
& $\lambda_{\text {Jul }}$ & $\lambda_{\text {Aug }}$ & $\lambda_{\text {Sep }}$ & $\lambda_{\text {Oct }}$ & $\lambda_{\text {Nov }}$ \\
\hline January & 6.9180 & 6.8306 & 6.2681 & 6.6332 & 6.8879 \\
February & 6.8091 & 6.8253 & 6.5773 & 6.7697 & 6.8216 \\
March & 6.3883 & 6.5404 & 6.7174 & 6.6740 & 6.4564 \\
April & 5.5558 & 5.8571 & 6.5164 & 6.2025 & 5.6846 \\
May & 4.7232 & 5.1244 & 6.1185 & 5.6147 & 4.8924 \\
June & 4.2864 & 4.7287 & 5.8648 & 5.2798 & 4.4722 \\
July & 4.4882 & 4.9116 & 5.9825 & 5.4349 & 4.6664 \\
August & 4.9609 & 5.3367 & 6.2445 & 5.7899 & 5.4175 \\
September & 6.1340 & 6.3394 & 6.6865 & 6.5480 & 4.5448 \\
October & 6.7138 & 6.7686 & 6.6404 & 6.7665 & 6.2238 \\
November & 6.9080 & 6.8422 & 6.3444 & 6.6740 & 6.7421 \\
December & 6.9157 & 6.8002 & 6.1539 & 6.5647 & 6.8868 \\
Monthly average & 5.9001 & 6.0754 & 6.3429 & 6.2460 & 6.8741 \\
Annual totals & 70.801 & 72.905 & 76.114 & 74.951 & 6.7927 \\
\hline
\end{tabular}

TABLE 5: Solar PV energy output at the four defined configurations.

\begin{tabular}{|c|c|c|c|c|}
\hline \multicolumn{5}{|c|}{ Solar PV energy output (kWh/m²/day) } \\
\hline & $\begin{array}{l}\text { Baseline region tilt angle } \\
\left(15^{\circ}\right)\end{array}$ & $\begin{array}{l}\text { Static monthly tilt } \\
\text { angles }\end{array}$ & $\begin{array}{c}\text { Static September tilt angle } \\
\left(\lambda_{\text {Sep }}\right)\end{array}$ & $\begin{array}{c}\text { Dynamic optimized monthly tilt } \\
\text { angles }\end{array}$ \\
\hline January & 6.7619 & 6.9295 & 6.2681 & 6.9402 \\
\hline February & 6.8198 & 6.8061 & 6.5773 & 6.8253 \\
\hline March & 6.6168 & 6.7189 & 6.7174 & 6.7189 \\
\hline April & 6.0234 & 6.2109 & 6.5164 & 6.5164 \\
\hline May & 5.3522 & 4.9215 & 6.1185 & 6.1185 \\
\hline June & 4.9825 & 4.0933 & 5.8648 & 5.8648 \\
\hline July & 5.1534 & 4.4882 & 5.9825 & 5.9825 \\
\hline August & 5.5487 & 5.3367 & 6.2445 & 6.2445 \\
\hline September & 6.4478 & 6.6865 & 6.6865 & 6.6865 \\
\hline October & 6.7865 & 6.7665 & 6.6404 & 6.7786 \\
\hline November & 6.7867 & 6.8868 & 6.3444 & 6.9212 \\
\hline December & 6.7142 & 6.9497 & 6.1539 & 6.9497 \\
\hline $\begin{array}{l}\text { Monthly } \\
\text { average }\end{array}$ & 6.1662 & 6.0662 & 6.3429 & 6.5456 \\
\hline Annual totals & 73.9939 & 72.7946 & 76.1147 & 78.5471 \\
\hline
\end{tabular}


TABLE 6: Space and cost specifications.

\begin{tabular}{|c|c|c|c|c|c|}
\hline $\begin{array}{l}\text { Site: } 1.4753 \mathrm{~S}, 36.95777 \text { E. Energy } \\
\text { requirement: } 100,000 \mathrm{Wh} / \text { day }\end{array}$ & $\begin{array}{l}\mathrm{PV} \text { wattage } \\
\text { required }(\mathrm{W})\end{array}$ & $\begin{array}{l}\text { KM375M-66H PV } \\
\text { modules (no.) }\end{array}$ & Overall space $\left(\mathrm{m}^{2}\right)$ & Overall cost $(\$)$ & $\begin{array}{l}\text { Cost and space } \\
\text { savings (\%) }\end{array}$ \\
\hline \multicolumn{6}{|l|}{ Configuration 1} \\
\hline $\begin{array}{l}15 \text { tilt angle } \\
6.1662 \mathrm{kWh} / \mathrm{m}^{2} / \text { day }\end{array}$ & 16215.34 & 43 & 79.39 & 3080.91 & 0.00 \\
\hline \multicolumn{6}{|l|}{ Configuration 2} \\
\hline $\begin{array}{c}\text { Static monthly tilt angle } \\
6.0662 \mathrm{kWh} / \mathrm{m}^{2} / \text { day }\end{array}$ & 16393.44 & 44 & 80.26 & 3114.75 & -1.10 \\
\hline \multicolumn{6}{|l|}{ Configuration 3} \\
\hline $\begin{array}{l}\text { Static September tilt angle } \\
6.3429 \mathrm{kWh} / \mathrm{m}^{2} / \text { day }\end{array}$ & 15765.41 & 42 & 77.19 & 2995.43 & 2.77 \\
\hline \multicolumn{6}{|l|}{ Configuration 4} \\
\hline $\begin{array}{l}\text { Dynamic monthly tilt angles } \\
6.5456 \mathrm{kWh} / \mathrm{m}^{2} / \text { day }\end{array}$ & 15276.50 & 41 & 74.79 & 2902.00 & 5.79 \\
\hline
\end{tabular}

would improve daily solar energy output by up to $2.87 \%$ as compared to the current industry practice. On the contrary, the dynamic tilt angle would improve the solar output by up to $6.15 \%$. Using the same configurations, cost and space savings analysis were done for a system with a daily energy requirement of 100,000 Wh/day. It was observed that the use of the optimum static tilt angle $\left(\lambda_{\text {sep }}\right)$ results in a cost and space saving of up to $2.8 \%$ as compared to the standard industry practice, in this particular case. On the contrary, a $5.8 \%$ cost and space savings were attained by the utilization of the dynamic tilt angle. Therefore, the developed algorithms can effectively be used to accurately determine the maximum possible energy generation from PV setups installed at specific geographical locations and thereby provide a design approach that ensures specific load demands are met without the common challenges of oversizing and undersizing PV systems and the consequent unnecessary costs and space challenges.

\section{Abbreviations}

A: $\quad$ p-n junction ideality factor

AM: Air mass

Ah: Ampere hours

$\mathrm{CO}_{2}$ : Carbon dioxide

DSR: Direct solar radiation

$\mathrm{E}_{\mathrm{G}}$ : Semiconductor bandgap

$\mathrm{eV}$ : Electron voltage

$G$ : Global irradiance

GHR: Greenhouse gas

$K_{i}$ : $\quad$ Short circuit current temperature coefficient

I: $\quad$ PV array output current

$I_{D}: \quad$ Intensity

$I_{r s}: \quad$ Reverse saturation current

$T_{r}$ : $\quad$ Reference temperature

$I_{r r}: \quad$ Reverse saturation temperature at $T_{r}$

$I_{s c r}: \quad$ Short-circuit current at reference temperature and radiation

$I_{p h}: \quad$ Photocurrent (A)

$P$ : $\quad$ Power

PV: Photovoltaic

Rs: $\quad$ Series resistance

$R_{s h}$ : Shunt resistance
S: $\quad$ Solar radiation $\left(\mathrm{mW} / \mathrm{cm}^{2}\right)$

$T: \quad$ Cell temperature $(\mathrm{K})$

$T_{S R}$ : Sunrise time

$T_{S S}: \quad$ Sunset time

$V: \quad$ PV array output voltage

$\delta$ : Declination angle

$\varphi$ : $\quad$ Latitude $\left({ }^{\circ}\right)$

$\omega_{s}$ : Sunset angle

$\alpha$ : $\quad$ Solar altitude

$n_{s}$ : Number of cells in series

$n_{p}$ : Number of cells in parallel

$q$ : Charge of an electron

$k$ : Boltzmann's constant

$Z$ : $\quad$ Zenith angle

$\omega(t)$ : Hour angle

$\lambda: \quad$ Tilt angle.

\section{Data Availability}

The simulation data used to support the findings of this study are included within the article and are available from the corresponding author upon request.

\section{Conflicts of Interest}

The authors declare that they have no conflicts of interest.

\section{References}

[1] K. M. Seetharaman, S. Nitin Patwa, and Y. Gupta, "Breaking barriers in deployment of renewable energy," Heliyon, vol. 5, no. 1, 2019.

[2] A. Shahsavari and M. Akbari, "Potential of solar energy in developing countries for reducing energy-related emissions," Renewable and Sustainable Energy Reviews, vol. 90, pp. 275291, 2018.

[3] X. Zou, Yu'e Li, K. Li et al., "Greenhouse gas emissions from agricultural irrigation in china. mitigation and adaptation strategies for global change," Mitigation and Adaptation Strategies for Global Change, vol. 20, pp. 295-315, 2015.

[4] J. Vanschoenwinkel and S. Van Passel, "Climate response of rainfed versus irrigated farms: the bias of farm heterogeneity in irrigation," Climatic Change, vol. 141, no. 2, 2018. 
[5] A. K. Shaker Al-Sayyab, Y. Zainab, T. Al, and M. K. Taher, "Theoretical and experimental investigation of photovoltaic cell performance, with optimum tilted angle: Basra city case study," Case Studies in Thermal Engineering, vol. 14, 2019.

[6] Africa Energy Series, Kenya Special Report 2020, Africa Oil \& Power, 2020, https://www.africaoilandpower.com/wp-content/ uploads/2020/03/AES_Kenya-Special-report-2020.pdf.

[7] S. A. Sarkodieand, S. Adams, and T. Leirvik, "Foreign direct investment and renewable energy in climate change mitigation: does governance matter?", Journal of Cleaner Production, vol. 263, 2020.

[8] G. Pearce-Oroz, Climate Change Strategies 2020, Climate Technology Centre \& Network, 2020, https:/www.ctc-n.org/sites/ www.ctc-n.org/files/climate_change_strategies_2020._final._with_ links_0.pdf.

[9] J. S. Fonash, Solar Cell Device Physics, Elsevier printing press, Oxford, UK, 2nd edition, 2010.

[10] R. Singh and R. Banerjee, "Impact of solar panel orientation on large scale rooftop solar photovoltaic scenario for Mumbai," EnergyProcedia, vol. 90, pp. 401-411, 2016.

[11] J. I. Laveyne, D. Bozalakov, G. Van Eetvelde, and L. Vandevelde, "Impact of solar panel orientation on the integration of solar energy in low-voltage distribution grids," International Journal of Photoenergy, vol. 2020, Article ID 2412780, 13 pages, 2020.

[12] M. Jacobson and V. Jadhav, "World estimates of pv optimal tilt angles and ratios of sunlight incident upon tilted and tracked pv panels relative to horizontal panels," Solar Energy, vol. 169, pp. 55-66, 2018.

[13] E. Mahdi, S. Abdul-Wahid, S. Abdulstar, S. Sahab, and A. Mosli, "Optimum orientation of solar panels in Baghdad city,” Journal of Basrah Researches, vol. 37, 2011.

[14] S. A. Alkaff, N. H. Shamdasania, G. Yun, and V. Kumar Venkiteswaran, "A study on implementation of pv tracking for sites proximateand away from the equator," Process Integration and Optimization for Sustainability, vol. 3, pp. 375-382, 2019.

[15] A. Awasthi, A. Shukla, M. Manohar et al., "Review on sun tracking technology in solar pv system," Energy Reports, vol. 6, pp. 392-405, 2020.

[16] R. Abdallah, A. Juaidi, S. Abdel-Fattah, and F. ManzanoAgugliaro, "Estimating the optimum tilt angles for southfacing surfaces in Palestine," Energies, vol. 13, 2019.

[17] M. A. Kallioğlu, A. Durmus, H. Karakaya, and A. Yılmaz, "Empirical calculation of the optimal tilt angle for solar collectors in northern hemisphere," Energy Sources, vol. 42, 2019.

[18] G. Hailu and A. S. Fung, "Optimum tilt angle and orientation of photovoltaic thermal system for application in greater Toronto area, Canada," MDPI Sustainability, vol. 11, 2019.

[19] N. David Ndungu, "A feasibility study on the effect of soiling on the performance of solar pv water pumping systems in Nairobi," M.S. thesis, Nairobi University, Nairobi, Kenya, 2017.

[20] E. Siegel, This is How the Sun Moves in the Sky throughout the Year, Forbes, Jersey, NJ, USA, 2019.

[21] I. Sarbu and C. Sebarchievici, Solar Heating and Cooling Systems; Fundamentals, Experiments and Applications, Academic Press, 2017.

[22] Z. Wang, Design of Solar Thermal Power Plants, Academic Press, Cambridge, MA, USA, 2019.

[23] A. Martinez-Gracia, I. Arauzo, and J. Uche, "Solar hydrogen production: processes, systems and technologies," Chapter 5-
Solar Energy Availability, Academic Press, Cambridge, MA, USA, 2019.

[24] A. Karafil, H. Ozbay, M. Kesler, and H. Parmaksiz, "Calculation of optimum fixed tilt angle of pv panels depending onsolar angles and comparison of the results with experimental study conducted in summer in Bilecik, Turkey," in Proceedings of the International Conference on Electrical and Electronics Engineering (ELECO), IEEE, Bursa, Turkey, November 2015.

[25] J. S. Cheetah Brochure. https://www.jinkosolar.com/uploads/ Cheetah2020.

[26] D. Feldman and R. Margolis, Solar Industry Update: Q4 2019/ Q1 2020, National Renewable Energy Laboratory (NREL), Denver, CO, USA, 2020. 